\title{
The transition of Southeastern European societies towards civil democracy and market economy: problems and perspectives
}

La transition des sociétés de l'Europe du Sud-Est vers la démocratie et l'économie de marché : problèmes et perspectives

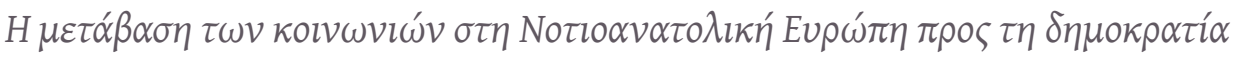

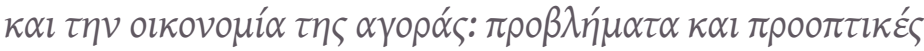

\section{Miltiades Kipas}

\section{CpenEdition}

\section{Journals}

Electronic version

URL: https://journals.openedition.org/ceb/14869

DOI: 10.4000/ceb.14869

ISSN: 2261-4184

\section{Publisher}

INALCO

Printed version

ISBN: 9782858313341

ISSN: 0290-7402

\section{Electronic reference}

Miltiades Kipas, "The transition of Southeastern European societies towards civil democracy and market economy: problems and perspectives", Cahiers balkaniques [Online], 46 | 2020, Online since 08 January 2020, connection on 06 July 2021. URL: http://journals.openedition.org/ceb/14869; DOI: https://doi.org/10.4000/ceb.14869

\section{(क) $(1)$}

Cahiers balkaniques est mis à disposition selon les termes de la Licence Creative Commons Attribution - Pas d'Utilisation Commerciale 4.0 International. 


\title{
The transition of Southeastern European societies towards civil democracy and market economy: problems and perspectives
}

\author{
La transition des sociétés de l'Europe du \\ Sud-Est vers la démocratie et l'économie de \\ marché: problèmes et perspectives

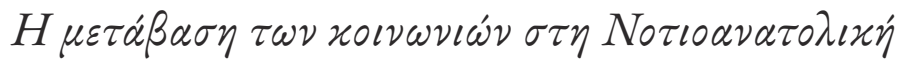

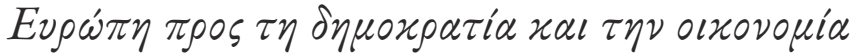

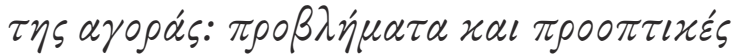

\author{
Miltiades Kipas \\ Alternate Professor, Panteion University of Athens \\ of Political and Social Sciences
}

After the destruction of the centrally planned economies in Eastern Europe, the governments that came into power tried to create new institutions able to adapt to the needs of the new era and the demands of the neoliberal economy, the dominant ideology of our times. Besides, for these new States, the possibility of financial aid depended on the implementation of the demands of the international organizations, which finance the newly funded societies, like the IMF (International Monetary Fund). On the other hand, these countries had to leave the single-party political system, in which the Communist party was predominant, and try to implement conditions of pluralistic civil democracy.

In many cases, these efforts have a dramatic effect on the social conditions: unemployment, which was previously hidden, increased quickly, ${ }^{1}$ inflation, which at the beginning followed quite often radical changes, finally decrease of the standard of living, which in most cases was already low. At the same time, the end of government aid to the households turned things into worse. A quite striking element is, as Deacon pin-points, that up to 1992 the old government mechanism regulated price changes with decrees, and at the same time compensated substantial parts of the population for the consequences that

1. Deacon, 1996, p. 293. 
were created by such increases. ${ }^{2}$ There is no in-depth analysis by social scientists for the change and overthrow of the old state mechanism after the velvet revolution of 1989. The old state mechanism seems to regulate the new era and the transition of these societies into the market economy, the only one to end up in prison is the Secretary General of the communist party in East Germany, Erich Honecker.

On these grounds, we are studying the reduction of State control that occurred in these countries and the new hopes that came from neoliberals for the speed up process towards the market economy along with the fans of the so-called actually existing socialism for the final outcome of the transition process towards capitalism, ${ }^{3}$ with a growing interest for the problems and perspective of the transition in the whole Balkan societies. ${ }^{4}$

\section{The rhetoric of change after 1989}

After 1989, several Western philosophers like Samuel Huntington tried to explain the process of instability in the Balkans and to justify military intervention. According to them, the hostilities were attributed to a kind of inherited hatred between the Balkan peoples, predetermined to be in continuous conflict because of their cultural divisions. ${ }^{5}$ It is clear that the conflict of civilizations theory, as philosophy, goes through and in depth every aspect of liberal western thought, in order to justify any intervention in sensitive areas such as the Balkans.

Clearly the nationalistic reasoning goes through the conscience of the Balkan populations but it doesn't involve the exclusive privilege of the countries of Southeast Europe. Nationalistic conflicts and unrest appear in many areas in the planet, like Africa, Asia, even in Europe, for example the struggle of the Basques, the effort for administrative autonomy in Catalonia, even the guerilla army of the IRA and generally where minorities exist. In an account of the war in the Balkans, we see that these wars are identified either as "unthinkable" or described as "balkanic butchery", and lead us to the conclusion that we have to do with a doubtful peninsula which is not yet European! ${ }^{6}$
2. Ibid, p. 307.
3. Fотороulos, 1993, p. 39.
4. For the main lines of the Balkan historical background and the new post-1990 conditions, see in French, Cattaruzza \& Sintès, 2012.
5. GOLDSWORTHY, 2002, p. 26.
6. Ibid., p. 29 
A closer study is needed so as to completely understand the phenomena that are predominant after 1989, a study which will explain the co-existence of different nationalities, and at the same time, understand to what extend democracy prevailed in these countries. Bulgaria, Romania and Albania along with the biggest part of former Yugoslavia constitute the southeastern European Balkans. It is clear that the culmination of democracy has faced there long-term obstacles greater than those faced in Central and Eastern Europe. Foreign attacks stopped the development of institutions, except for the Christian orthodox church, and at the same time retarded the growth of a western development plan for private liberty. ${ }^{7}$

Long-term Turkish subjection and subsequent wars between the Ottoman Empire and the Opposite powers, have caused many populations shifts, "voluntary" or not. The complex coexistence of languages and religions, even that of "minorities", means that the Balkans is a compound ethnic mosaic that creates great difficulties to any government that tries to keep in power and balance any political system and society based on the Nation-State ideal. The first contact with the democratic regime was unsuccessful, and started prior or immediately after World War I.

It was difficult for the weak Balkan states to unite their populations, different as to their national feelings, and who faced intense financial and economic inequalities. ${ }^{8}$ No domestically trade-oriented middle class could be committed so as to establish political institutions and the law seemed to serve as a fortress for democratic governments.

At any rate the prewar failure isn't only attributed to non-promising conditions, to unfit leaders or to socioeconomic impoverishment. It is clear that there were deeper reasons having a greater impact in the region as it is proved today, 60 years later. Traditions concerning individual freedom were weak. ${ }^{9}$ Freedom actually meant freedom concerning the choice of foreign influence and not exactly freedom of the right of individual as such as to express disagreement on government positions or disagreement from the opinion of the majority. Many citizens either ignored the existence of their rights, or even were afraid to practice them. ${ }^{10}$

7. Gallagher, 1998, p. 43.

8. Ibid., p. 43.

9. Ibid., p. 44.

10. Ibid., p. 44 
According to Miall, a traditional anarchic state system still exists in the Balkans, which predetermines the issue of power in the relationship between States. ${ }^{11}$ The same could also apply for Central Europe, for example in Czechoslovakia where two different States were formed, Slovakia and the Czech Republic. In Slovakia, Romania, and Serbia the issue of the Magyar community has to be solved as well. Nonetheless, the "nations mosaic" rationale cannot at any rate constitute an alibi so as to explain wild wars and thus adopt a racist belief based on the difference of civilization and culture. At any rate the issues of the prerogatives of the minority constitute major international concern and are not a simple internal political problem. ${ }^{12}$

Furthermore, the situation doesn't justify the vulgarity or the zeal that the West showed over the bombarding of Yugoslavia. The NATO bombarding of Yugoslavia aimed first at beleaguering its defense, and second destructing its industrial and economic infrastructure. ${ }^{13}$ Also, we must never forget that the South-East Europe geographically is at the edge of Europe and is directly related to the cultural traditions of two more states, Romania and Bulgaria newly entered in Europe. Besides the country with the greatest minority problem is Turkey, which after the 1920's didn't face any problems of the "balkanic butchery" type (except the Kurdish question!), despite the abolition or limitation of personal individual rights and the perpetration of atrocities at times. It is clear that with its geopolitical position and its usefulness in the Middle East, the countries of developed capitalism had to manage Turkey in a different way. Maybe, because of the Balkans' geographical position in the geopolitical map, fragmentation and unrest contribute to certain solutions in favor of the interest of the West.

\section{Political and social challenges}

We have already mentioned the nationalistic problem, which is present to a greater or a lesser extend in the countries of the Balkan peninsula. After 1989, the "minority problem" was part of the political reforms that governments had to meet. The solution for them consists in an effort in parallel and in continuation of the efforts from the times of central planning systems, meaning adjustments into a new era of civil democratization, enforcement of parliamentary systems and civil liberties. The particularities of each country, led the problem either to its

\footnotetext{
11. Miall, 1993, p. 22.

12. PRICE, 1998, p. 261.

13. Kipas, 2004, p. 513.
} 
gradual absorption of the shocks, or to greater aggravation with unpredictable final consequences. What gives a striking impression is that the institutions of the previous system are used for the transition process towards the market economy, and what is also of interest is the essential difference between the parliamentary system, or in general the civil democracy which is being created, in relation to the structure and function of institutions of the previous social system. It is worth giving a very quick view of these new elements and even seeing the characteristics of the new market economy in these particular countries, at least in the first years of reform.

In Romania national independence was pumped by nationalism, based on the pride Romanians felt for the historic ascendants of their society, as quite often among the Balkan States. ${ }^{14}$ They traced back the history of their country back in the Roman Empire, which had established a political guard where today's Romania is, naming the region as Dacia. Romanians believe that the neighboring countries including Russia ${ }^{15}$ are sons of this Dacian state. They are also proud of their eastern cultural tradition and of their language, which made them differ from their Slav neighbors. Along these standards, Romanian excellence was cultivated by Ceaușescu during his governance. Basically, Romanian nationalism comes from a historic fear and hatred for the Russians who always made efforts to siege Romanian territories during the $19^{\text {th }}$ and early $20^{\text {th }}$ century. ${ }^{16}$ It evolved to a great extend in the '70's and '80's after the harassment of Hungarians in Transylvania, and the persecution of the few Jews that were left in Romania after World War II.

In this framework, the Ceaușescu regime developed its politics, and punished the critics concerning his practices and leadership. The police exerted huge power on the citizens life, and the country had the greatest proportion of secret police to population, in Eastern Europe. Ceaușescu organized a stalinistic type of power and leadership, developing his own cult to enforce the base of his power. He tried to implement what was historically inapplicable, that is, to stop the flow of history and identify his name with Romania. Here are two well-known examples ${ }^{17}$ : first, he sought to the politics of urbanization in the framework of which thousands of villages had to be razed and complexes of buildings of the industrial-agricultural type had to be created to house farmers and workers. Secondly, he razed to the ground the historic center of Bucharest, which was considered as the "Paris" of the

14. Goldman, 1997, p. 268.

15. Ibid., p. 268.

16. Ibid., p. 268.

17. Mourtos, 1994, pp. 647-648. 
Balkans, in order to build his own luxurious palace. With this policy, he sought to move $90 \%$ of the urban centers population and reside them in new suburbs and in new state flats. His aim was first to destroy every space of passive resistance, mainly of the people in the rural areas who wouldn't be easily controlled, creating in this way a concentration camp society. Second, to create a type of citizen that would function collectively in the framework of his personal perception of socialism. In this way he tried to create a new cultural society constituted by subjects with no history. ${ }^{18}$

After his overthrow and his execution in 1989, the following government under Iliescu, tried to create a new situation with new practices such as the abolition of censorship, the approval of non-communist groups or organizations, and the free assembly of people. However, the new leadership, showing survivals of the old regime, didn't want to share power with the newly funded parties. So, a kind of authoritarianism still existed, which actually was a continuation of the past. Independent newspapers had difficulties in purchasing newsprint and to make deals of distribution. ${ }^{19}$ It is quite impressive that the Front under Iliescu, even after it was split, and along with the forces of opposition, didn't share any differences as far as the philosophy of the statute of ownership after 1989 is concerned. After the 1990 elections, in which Iliescu won $85 \%$ of the votes, as well as the 1992 elections, the issues of privatization and the foundation of individual property were in the agenda. The only question was the rate of privatization and under which government it would occur. We also have accusations from the opposition about the authoritarian behavior of the Iliescu government. The easy change from one type of ownership to another with no further consequences (apart from the Ceaușescu execution), on the members of the old regime which constituted the body of the new regime, should be a subject of investigation for the kind of societies that were prevalent prior 1989.

Bulgaria had its own minority problem. Characteristic example is that during the winter 1984-1985 the government begun a massive campaign for the change of names of the Turkish population. ${ }^{20}$ This however wasn't the first effort to change the names in order to "bulgarize" or "slavicize" them, there were already such attempts in 1912-1913, 1941-1944 and in 1971. ${ }^{21}$ What was even more important was the fact that this whole effort couldn't find any justification as there

18. Ibid., p. 648.

19. Goldman, 1997, p. 279.

20. Todorova, 1992, p. 154.

21. Ibid., p. 155. 
was no special opposition of Turkish population, 9,49\% of the total Bulgarian population in 1965 , to the regime. ${ }^{22}$

The communist party prevailed in Bulgaria right after World War II. The social system of Bulgaria functioned at the framework of republican centralization imposed by article 5 of the 1971 Constitution, and didn' $t$ face the violence of the Ceaușescu regime. ${ }^{23}$ In the Bulgarian constitution the term "planning" concerned the whole economy and society as well. The wave of political change carried away communist Bulgaria in 1989. Its main characteristic is that in the new era the process towards democracy, at least in the first years, was achieved by the very same mechanism, which for the last five years gave room for the central planning to be implemented, projecting the interests of a strong political group. After 1989 and during the first years, Bulgaria didn't manage to keep up with the pace of Central and Eastern Europe. In 1992, the government tried to undergo a scheme of total liberalization of the market but the results were quite disappointing. ${ }^{24}$ Another crucial element is that, in the 1990 elections, the Communist party, transformed into the Bulgarian Socialist party, was the winner, it was, with free elections, the most powerful communist party in Eastern Europe after 1989. This very same party draws a new constitution adapted to the needs of civil parliamentary democracy. ${ }^{25}$ In the 1991 election, the opposition, being the winner, carried on at a faster pace with the practices of the Bulgarian communist party. At the same time the financial situation of the workers worsened.

Yugoslavia brought together Slavic and non-Slavic cultural groups with various cultural environments, backgrounds ${ }^{26}$, different cultural traditions and levels of financial prosperity ${ }^{27}$. The State organization was based on five national groups with their own unities, called Republics after World War II. With their historical background, in Croatia and Slovenia, the Western perception concerning political individuality and the economy were more easily developed ${ }^{28}$, and, on the contrary, the Turkish supremacy brought little to social and economic

22. Kentrotis, 1994, p. 327.

23. Ibid., p. 229.

24. KipAs, 2004, p. 108.

25. Kentrotis, 1994.

26. Prior to 1918, the Slovenians, the Croatians and the Bosnians were part of Austro-Hungary, while the Serbs and the Montenegrins and the Macedonians were part of the Ottoman Empire.

27. Goldman, 1997, p. 299.

28. Ibid., p. 301. 
maturity in the southern Republics. This resulted in different social groups having different levels of economic prosperity. Slovenia and Croatia were more developed and had a kind of European standard of living, with industrial areas, advanced telecom and transport. Serbia had an industrial sector but it was primarily an agricultural area with a less modern structure compared to the northern Republics ${ }^{29}$. Montenegro and Macedonia had a much less developed infrastructure due to less financial aid.

All of the Republics had "minorities", and, after World War II, they tried to reinforce their societies and to control their territories, inhabited by these minorities. Furthermore, of Tito's industrialization period during the ' 50 's, ' 60 's, and ' 70 's, broadening the gap between the town and the village, tended to project internal nationalistic prejudice, and to increase internal conflict. ${ }^{30}$ So, these internal differences between Northern, Central and Southern Yugoslavia got worse due as some areas remained extremely poor after World War II up to the 1980's. The Krajina in Croatia, the county of Kossovo in the Serbian Republic, and Macedonia presented slow economic adjustments and advances compared to Slovenia, Croatia and parts of Serbia like Vojvodina and the industrial area around Belgrade. The per capita income decreased in these areas. However, Tito succeeded in developing a kind of Yugoslavian nation and discouraging the centrifugal forces. ${ }^{31}$ Belgrade, Zagreb, and Sarajevo formed cosmopolitan places and were inhabited by people from different places, with different religion and language which told themselves Yugoslavian. The Yugoslav Communist Party was a unifying power, encouraging unity and faith in national predominance and central power.

Everything changed with Slobodan Milošević created a neostalinistic way of government ${ }^{32}$ and extolled Serbian nationalism leading to schismatic moves in Slovenia and Croatia that declared their national independence, or even to wars in Bosnia-Herzegovina, in Kossovo and even in Krajina, where lived a Serbian minority. To understand how naïve or propagandistically intentional are the views about civilizations' conflict, it is quite appropriate to refer to the role of European Union, especially Germany, or of the U.S.A. which, due to their economicmost of all-interests, had a quite opposite stance on the issue of the national independence of Croatia and Slovenia. Germany was in favor of the fragmentation of Yugoslavia, in contrast to the U.S.A. Under these circumstances, economics

29. Ibid., p. 302.

30. Ibid., p. 303.

31. Ibid., p. 303.

32. Ibid., p. 306. 
were hampered and the transformation of the market was time consuming. Also, the refugee problem from the regional wars created much more difficulties in the economy. The climax point was the war of the West in 1999 against new Yugoslavia leading thus to the destruction of the industrial infrastructure.

Albania was depending on the Ottoman Empire for centuries, and gained its independence at the beginning of the $20^{\text {th }}$ century. After World War II, the Albanian Communist party prevailed. The only "minority problem" was the Greek minority which went through different phases, according to diplomatic relations between the two States. Albania remained a closed economic state, internationally isolated as it has broken up its close relations with the Soviet Union in the '50's and with China as well after Mao's death, in the end of 1970's; it became the poorest country in Europe. For decades the predominant figure was that of Enver Hoxha ("the Red Sultan"). After his death, with Ramiz Alia as his successor, and under the pressure of social unrest, reforms started to take place. Alia created a wide range of political liberalization. Despite the persistence of the bureaucracy, he broke the monopoly of the Communist state, and in the ' 90 's and in the $21^{\text {st }}$ century Albania became a western type parliamentary republic. The opening of the market economy in parallel to political change led, as elsewhere in the South Balkan, to economic difficulty, more economic reform was needed; just don't forget that in 1991 most of the Albanians were using oxen, carriages and donkeys as a means of transportation. ${ }^{33}$

\section{Economic reformation}

To understand the process of transition, we must remember some characteristics of the centrally planned economic systems as these were developed in Eastern Europe. Some basic elements were:

- a hierarchical structure of power,

- central planning,

- commitment on the maximum utilization of resources,

- standardisation of goods and services,

- flexibility over control in prices,

- lack of return on money,

- lack oflegal alternative solutions in the already predetermined relationships,

- leading motives which involve planning. ${ }^{34}$

33. Ibid., p. 65.

34. Campos \& Corricelli, 2002, p. 795. 
The centrally planned societies asked for economic development. The planning prior to 1989 favored accumulation concerning structural and technological change. Although the mechanization process functioned until the '60's, the first crisis appeared with the very late growth in that period. At the same time the technological gap with the West began to widen. Two options were possible: 1) the creation of major technological advances, or 2) diffusion of technology in industries. ${ }^{35}$ The Soviet Union leadership went for the first choice, thus leading for the development of military technology. The oil crises of 1973 and 1979 obliged the West to vertically develop technological advances based on computers and on energy conservation issues, which didn't actually happen in Eastern Europe. ${ }^{36}$

These facts were of catalytic importance for many economists in the West. Additionally, this led to slow down the economic development, and consequently caused the great crisis of the ' 80 's and especially in 1989, which carried away the so-called actually existing socialism, and the Balkan countries as well. After 1990 the process towards the market economies started to evolve.

The process of transition for today's specialists has been connected with reformations on the institutional framework of the old systems, into the new rationales of political and economic content which corresponds to the new framework of parliamentary democracy and the market economy. The state mechanism of the old system decisively contributed to the reforms which in most cases were made by people of the old regime. What was finally changed? Wasn't only the metamorphosis of the Keynesian-Fordian State, after the two oil crises of 1973 and 1979, adjusted to the contemporary needs of the global economy, which didn't follow counter reforms? The privatisation of the public enterprises even in the ' 80 's wasn't based on the so-called flexible enterprises in contrast to the colossal monopolistic type enterprises that were dominant till then?

A major difference is the breakdown of a rationale of an economic model which didn't adjust at the proper time, while we have the violent adjustment of some countries into the new facts with "shock treatments." Main characteristic examples of this kind of tactic are Russia and Bulgaria. The rhetoric for the overthrow of Communistic regimes and their transformation into capitalistic systems must have been approved finally.

As far as the Balkans is concerned, the Romanian and the Bulgarian economy prior to 1989 were quite similar. Large scale enterprises were dominant in both countries: the enterprises occupying 501-5 000 workers produced $58,9 \%$ of the output in Bulgaria, whereas enterprises occupying over

35. Ibid., p. 795.

36. Ibid., p. 796. 
5000 workers produced $13 \%$ of the output. In Romania, enterprises occupying 501-5 000 workers produced 60,2\% of output and enterprises occupying more than 5000 workers produced $33,8 \%$ of output. In Albania which was the least developed country, enterprises occupying more than 501 and less than 5000 workers (these numbers didn't actually exist) produced $71,6 \%$ of output. ${ }^{37}$ With a simple law which contained reforms against monopoly and in favour of competition, reforms started to take place beginning in May 1991 in Bulgaria, August 1990 in Romania and December 1995 in Albania. ${ }^{38}$ Despite some differences the transition models in these countries followed the same pattern. Only the economic model of Yugoslavia had a significant deviation in relation to the other countries in Eastern Europe, because the reforms had a different content; it is quite evident from the kind of social ownership that the Yugoslav Communists had chosen.

We underline that the Balkans states because of their idiosyncrasy and economic evolution are more adjustable to the model of a developing country close to those of Central and Eastern Europe. ${ }^{39}$ This evolution may be understood by the system of social and class composition which existed before 1989 and by the changes after 1989 in the social groups among them. ${ }^{40} \mathrm{G}$. Eyal support the fact that the new civil class consists of the previous intellectuals and the ex-communist technocrat-managerial elite. ${ }^{41}$

The inflows of foreign direct investments in the pipeline of changeover constitute a significant breakthrough in the effort of constructing the economies of the Balkan Peninsula. The international trade is said to underly the foreign direct investments of the specific area. ${ }^{42}$ By using an econometric model which is based on the table of data analysis, we ascertain that both major factors, such as the destination, the population, the GDP, and less major factors or special factors necessary for the procedure of the changeover, such as the danger, the labour cost and the corruption could explain the size of the flows of the foreign direct investments to a great extent.

The foreign direct investments could be considered as a significant tool for the Balkan countries in order to cover their organizational gaps through the

37. Mintchev, 2001, p. 115, $117 \& 118$.

38. Ibid., p. 116, $117 \& 119$.

39. Dunning, 1993, pp. 230-231.

40. Kipas, 2004, pp. 203-207.

41. Eyal, Szelenyi \& Townsley, 1998, pp. 46-55.

42. JANICKI \& WUANAVA, 2004, p. 505-509. 
introduction of new techniques that concern either the management of the economy or the management of new technologies. However, in order to gain foreign direct investments, a policy and a macroeconomic stability are needed, with simultaneous transparent legal regulations in respect of others' property and the profits repatriation. ${ }^{43}$ There is a close connection between the flows of the foreign direct investments, the economic performance and the extractions. The foreign direct investments constitute a special characteristic of the economic accomplishment, since they pave the way for the acceleration of growth, the technological innovation and the restructuring of the enterprises. ${ }^{44}$

Apparently, a similar tax policy is also needed, as the high tax rates for the companies benefits decrease the yields of the foreign direct investments and discourage the entrance of similar capitals. ${ }^{45}$ Parallel to this, foreign direct investments are necessary in order to cover the organizational gaps of the economies of the specific countries to be, whether they concern the management of the economy or the management of the new technologies.

The per capita foreign direct investments in the Western Balkan increased from 383 dollars in 1995 to 3.839 dollars in 2008. The rise was much bigger in Slovenia which reached up to 7.852 dollars and in Croatia up to 7.002 dollars and the smallest one was noted in Albania with 829 dollars, while in Bosnia-Herzegovina it was 1.686 dollars, in F.Y.R.O.M., 2.121 dollars and in Serbia 2.225 dollars. In the South-Eastern Balkans the per capita foreign direct investments increased from 270 dollars in 1995 to 3.458 dollars in 2008. The largest part of the foreign direct investments came from European Union countries. ${ }^{46}$

The weaknesses of the Balkan countries economies came into focus after the crisis of 2008: a considerable problem in the productive fabric with the subsidence of the primary sector, and a spectacular growth of the services sector, simultaneous to the deindustrialization. This fact confirmed the weakness of the indigenous production to correspond to the demand. According to the official statistics of UNCTAD in 2009, the industry produced in the best-case scenario the $23,6 \%$ of the GDP in Romania and in the worst case scenario the $7,7 \%$ in Albania in 2008. ${ }^{47}$

43. Demekas, Horvath, Ribakova \& Wu Yi, 2005.

44. Garibaldi, Mora, Sahay \& Zettelmeyer, 2002.

45. Mateev, 2008, p. 9.

46. Babanasis, 2014, p. 82.

47. MAKRIS, 2014, p. 664. 
Finally, most countries of the North Eastern Europe restricted the inflation during the period of 2002-2011 in order to conform to the criteria of the European Union, with the exception of Serbia and Romania which continued to be characterized by a high inflation. They also restricted the budget deficits and the public debt to levels that approach the Maastricht criterion. ${ }^{48}$

\section{Epilogue}

The transition of the Balkan societies towards parliamentary democracy presents its own specifications. The extraordinary various cultural elements of the area and the problem of minorities shape the special transition from the model of centrally planned economy on which the Balkan countries were based before 1989, towards the market economy. The economic dynamics of the Balkan economies before 1989 play an important part in the readjustment of Balkan societies in the new era.

Any development constitutes an outcome of the international environment, especially of the great forces which in different ways intervened in the area, because of the important geopolitical position of the Balkans. We must stress that the theory of civilization's conflict cannot at any rate explain the developments that took place in the area the last fifteen years.

The fact that a brief and concise study couldn't interpret the co-existence of different ethnicities and comprehend the content of democracy in the Balkan region is quite important. The problem of the co-existence of populations that differed both in cultural heritage, national feeling and economic and social inequalities is not a new one. None indigenous or trade-oriented middle class was bounded to create political institutions a for democratic governments.

It is clear that the countries of the developed capitalism handle the Balkan States in a special way because of their geopolitical position on the road towards Russia and the Middle East. Nevertheless, the institutions of the former system were used in the transition to market economy and civil democracy. In any case, any development is also a consequence of the national environment and of the Great Powers that commingled in this area in many ways, and the theory circa clash of cultures cannot interpret any developments of the last fifteen years. The transition to the market economy of the Balkan countries is connected to a procedure of reconsideration in Europe, which is related to participation in the European Union, that is to say, the embodiment of the Balkan economies in the global economy, mainly through the trade and the capital flows.

48. Babanasis, 2014, p. 84. 
Politique et sociétés à Chypre aujourd'hui

In that respect, the creation of high technological breakthroughs and the diffusion of technology in the industries is of main importance. The foreign direct investments play a major role for this development, and consequently, the national trade. The foreign direct investments must be considered as a significant tool for the Balkan countries in order to cover their organizational gaps through the introduction of new techniques about management of the economy or of new technologies.

\section{BIBLIOGRAPHY}

\section{Books}

Cattaruzza Amaël \& Sintès Pierre, 2012, Atlas géopolitique des Balkans, un autre visage de l'Europe, Autrement, Paris, 96 p.

Dunning John.H., 1993, The Globalization of Business, Routledge, London \& New York, 482 p.

Eyal Gil, Szelenyi Ivan \& Townsley Eleanor, 1998, Making Capitalism without Capitalists, Verso, London \& New York, 280 p.

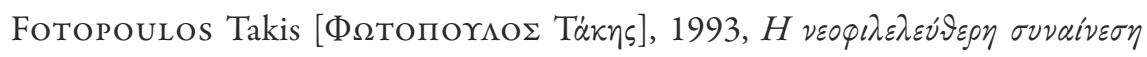

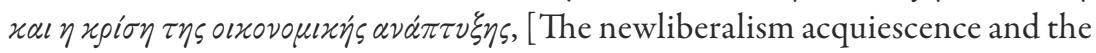

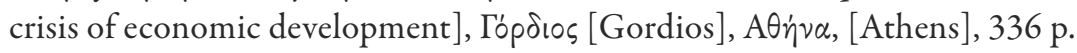

Goldman Andrew, 1997, Revolution and Change in Central and Eastern Europe, Routledge, London \& New York, London, 450 p.

Goldsworthy Vesna, 2002, Invention and In(ter)vention: The Rhetoric of Balkanization, in "Balkan as Metaphor", BJelic Dusan I. \& SAvic Obrad (eds.), MIT Press, Cambridge.

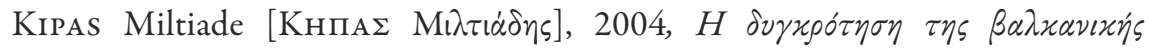

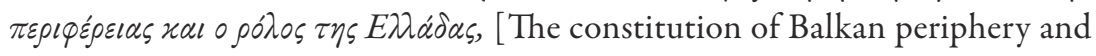

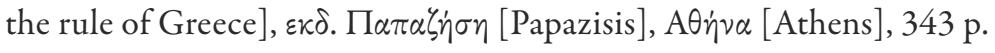

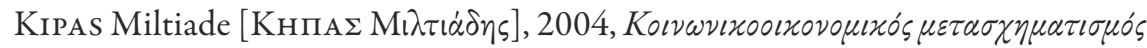

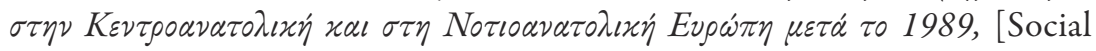


and economic transformation in Center and Eastern and Southeastern Europe

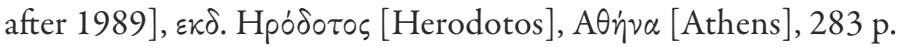

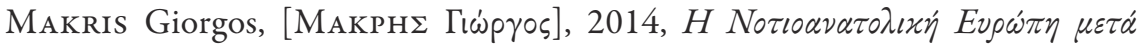

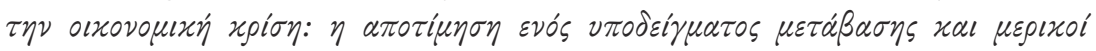

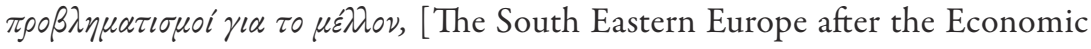
Crisis. An Appraisal of a Model of Transition and some Speculations for the

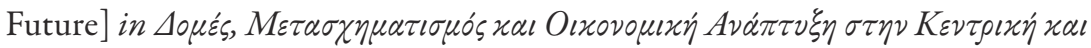

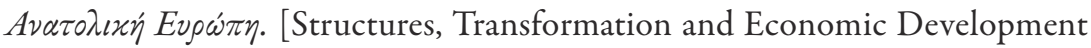

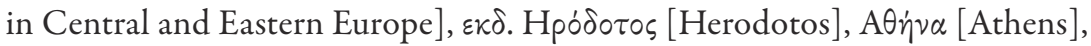
$1052 \mathrm{p}$.

Mateev Miroslav, 2008, Determinants of foreign Direct Investments in Central and Southeastern Europe: New Empirical Tests, $8^{\text {th }}$ Global Conference on Business \& Economies, Florence, Italy, 41 p.

Miall Hugh, 1992 Shaping the New Europe, Pinter, London.

\section{Papers, contributions to books}

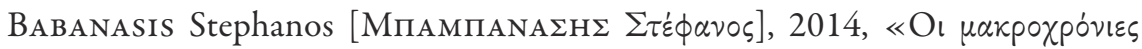

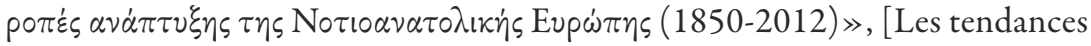
longues de développement en Europe centrale et orientale] in $\Delta о \mu \varepsilon \dot{s}$,

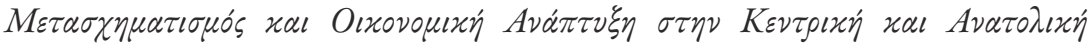

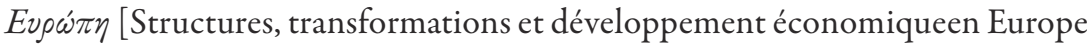

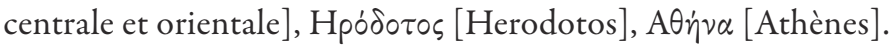

Campos Nauro \& Coricelli Fabrizio, 2002, "Growth in Transition: What we know, what we don't, and what we should", Journal of Economic Literature, Vol. XL.

Deacon Bob, 1992, "The future of social policy in Eastern Europe", in The New Eastern Europe, supervision B. Deacon, SAGE Publications, London, Newbury Park \& New Delhi.

Demekas Dimitri, Horvath Balasz, Ribakova Elina \& Wu Yi, 2005, "Foreign direct investments in South Eastern Europe: how (and how much) can policies help?", Working Paper $n^{\circ}$ 05/110, International Monetary Fund (IMF), European Department, Washington. 
Gallagher Tom, 1998, "The Balkans: Bulgaria, Romania, Albania and the Former Yugoslavia" in Developments in Central and East European Politics, St. White St., Batt J. \& Lewis P.G. (eds.), Macmillan Press Ltd, London.

Garibaldi Pietro, Mora Nada, Sahay Ratna \& Zettelmeyer Jeromin, 2002, “What moves capital to transition economies?", IMF Staff Paper ${ }^{\circ} 8$, Special Issue, International Monetary Fund, Washington.

Janicki Hubert \& Wunnava Phanindra, 2004, "Determinants of foreign direct investments: empirical evidence from EU accession candidates", Applied Economics, 36 (5), pp. 505-509.

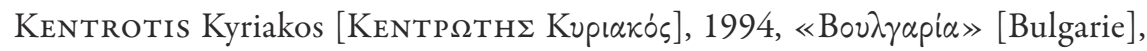

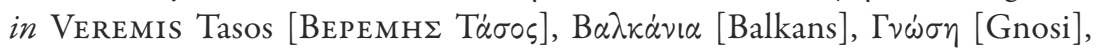
A $\theta \dot{\eta} v \alpha$, [Athènes], pp. 235-256.

Mintchev Vesselin, 2001, "Structural Reforms in Southeastern Europe and Privatization in Albania, Bulgaria and Romania" in Petrakos Georges \& Toтev Stoyan, The Development of the Balkan Region, Ashgate, Burlington. pp. 113-140.

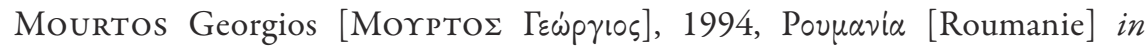

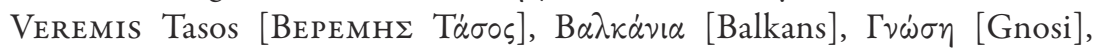
A $\theta \dot{\eta} v \alpha$, [Athènes], $1750 \mathrm{p}$.

Hyde-Price Adrian, "Patterns of International Politics" in Developments in Central and East European Politics, St. White St., Batt J. \& Lewis P.G. (eds.), Macmillan Press Ltd, London.

Todorova Maria, 1992, "Improbable Maverick or Typical Conformist? Seven Thoughts on the New Bulgaria" in BANAC Ivo, Eastern Europe in Revolution, Cornell University Press, New York. pp. 148-167.

Abstract: After the collapse of the centrally planned economies in Southeastern Europe, the new governments that came to power tried to create institutions capable of meeting the needs of new era and the imperatives of the neoliberal economy. They had to face the nationalist logic that penetrated the Balkan populations, similar to that of other parts of the world, such as Africa and Asia, or even in Europe such as Catalonia or the Basque struggle. 
A special study is required to understand the problems that have arisen in the Balkan region, such as population shifts, urban modernization after four decades of "existing socialism" with the particular characteristics of that era. It is also important to analyze the major socioeconomic developments that have taken place in the Balkan countries since 1989.

Keywords: Balkan peoples, nationalism, religion, resistance, institutions, democratization, economic reformation, Romania, Bulgaria, Yugoslavia

Résumé: après l'effondrement des économies planifiées du Sud-Est européen, les nouveaux gouvernements au pouvoir durent créer des institutions capables de répondre aux besoins de l'ère nouvelle et aux impératifs de l'économie libérale. Ils durent faire face au courant nationaliste qui pénétra les Balkans, comme d'autres parties du monde, Afrique ou Asie, ou même en Europe, au Pays basque ou en Catalogne. Une étude spécifique est nécessaire pour comprendre les problèmes qui ont surgi dans les Balkans, comme les déplacements de population, la modernisation urbaine après quatre décennies de «socialisme réel » avec les caractères de cette ère nouvelle. Il est aussi important d'analyser les développements socioéconomiques majeurs survenus dans les pays balkaniques depuis 1989.

Mots-clefs: populations balkaniques, nationalisme, religion, résistance, institutions, démocratisation, réforme économique, Roumanie, Bulgarie, Yougoslavie

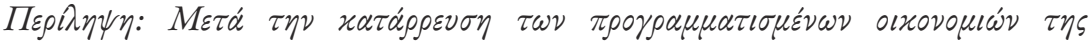

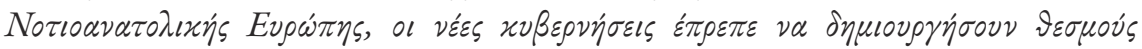

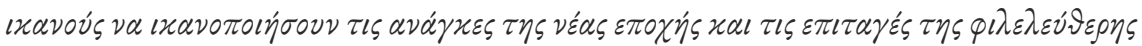

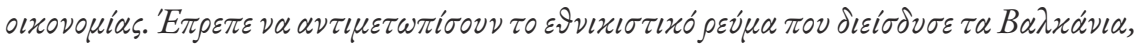

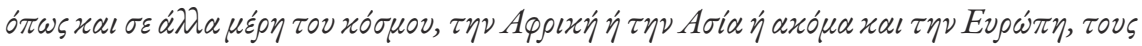

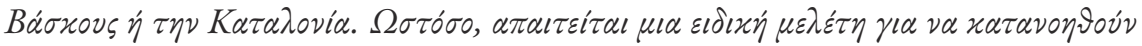

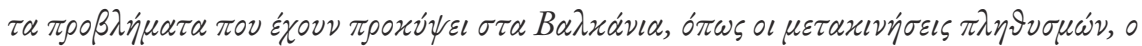

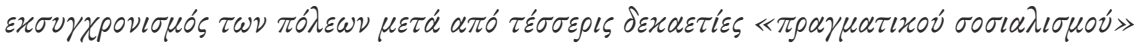

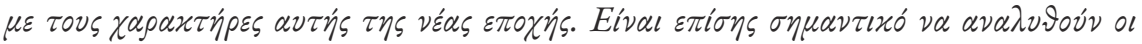

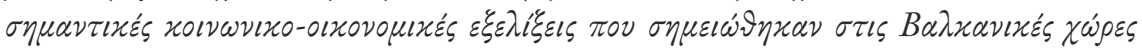
a

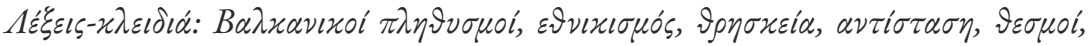

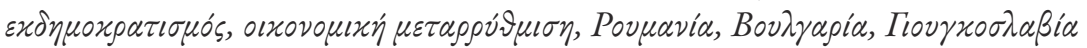

Anabtar kelimeler: Balkan nüfusu, milliyetçilik, din, direniş, kurumlar, demokratikleşme, ekonomik reform, Romanya, Bulgaristan, Yugoslavya 
Клучни зборови: Балканското население, начионализмот, религијата, отпорот, институциите, демократизачијата, економските реформи, Романија, Бугарија, Југославија 